\title{
The Missional Future of Free Churches in a Secular Context: A German Case Study
}

\author{
Stefan Paas \\ Vrije Universiteit Amsterdam \\ Theologische Universiteit Kampen \\ University of Pretoria \\ s.paas@vu.nl \\ Philipp Bartholomä \\ Freie Theologische Hochschule Gießen \\ bartholomae@fthgiessen.de
}

\begin{abstract}
Similar to most Western nations, Germany has experienced a history of secularization, resulting in church decline. However, some Christian communities have been less affected by decline. The historical free churches (Freikirchen), usually of an evangelical nature, have not only developed a more explicit missionary identity than the mainline churches, some of them have also been able to experience church growth against the larger trends. In this paper quantitative and qualitative data are presented based on a study of the Bund Freier evangelischer Gemeinden (BFeG) in Germany. These data show that general church growth and conversion growth are correlated, that young churches grow better (in both respects) than older churches, that the net conversion growth (conversions minus decline) of younger and older churches is overall largely the same, and that growth results in Berlin outperform the results in other cities and in the BFeG as a whole. These results are put into context by extended case studies of two churches, one old and one young, and they are discussed with a view to existing studies of (free church) mission in the West.
\end{abstract}

\section{Keywords}

church growth - conversion growth - mission - secularization - free churches - Bund Freier evangelischer Gemeinden 
While Christian churches in most European nations have suffered extensively from what can be summarized as 'secularization', resulting in a massive loss in numbers, the classic free churches (Geldbach 2005; Voigt 2004) seem to have avoided this fate so far. A recent study into thriving evangelical free churches ${ }^{1}$ in the Netherlands presented them as offering 'protective umbrellas of conservative belief', allowing them to grow-at least for the time being-even in a very secular context (Vermeer \& Scheepers 2017). Also, free churches such as Baptists and Pentecostals have been among the most vigorous planters of new churches, with a strong intention to make converts, achieve church growth, and impact societies (Paas 2016, 61-88).

Germany is no exception to this two-fold development. Church decline has been steep here, especially in the East (Großbölting 2013; cf. also Meulemann 2015), ${ }^{2}$ yet the historical Freikirchen show a pattern of a mission-oriented rhetoric in many cases, and actual membership growth at least in some instances (Bartholomä 2017). Generally speaking, the German free churches have historically defined themselves to a significant degree as the antitypical counterpart of the mainline churches within a society that was largely perceived as Christian. This is to say that their collective ecclesiological (and thus also missional) identity was formed in opposition to the large churches (Protestant and Catholic) as their 'significant others' (Bartholomä 2015). On the level of practical recruitment, the presence of large populations of so-called 'nominal Christians' were a suitable fishing pond for the free church movement, not just in Germany but in other nations as well. Hence, free churches traditionally operated in a 'revivalistic mode', primarily reaching those who had already been religiously socialized to a significant degree (Paas 2016, 101-105; cf. also Bartholomä 2014).

This raises the question to what extent the classic free church approach of mission is still effective in a more deeply secularized society, where 'nominal' church members are less in stock. While some studies suggest that the free churches still combine resilience against secularizing forces with a significant competitive strength (Stolz \& Favre et al. 2014; Vermeer \& Scheepers 2017),

1 Historically, the label 'free' refers to an organization type of church independent from the state (non-establishment), and usually on a congregationalist basis (autonomy of local congregations). 'Evangelical' refers to a theological tradition as exemplified by most free churches. Here the labels are used alternately.

2 Since 1990 the Roman-Catholic Church in Germany has lost about 5 million members (now approx. 23 million), the German Protestant Church (EKD) has lost about 10 million (now approx. 21 million). 
others have insisted that the noticeable 'crisis of mission' in Europe pertains to the realm of the classic free churches as well, as they are now especially struggling to reach the growing segments of society that are thoroughly unchurched (Schröder 2007; Bartholomä 2017). Also Vermeer and Scheepers believe that 'decreasing numbers of orthodox believers' in the Netherlands will gradually affect the recruitment success of evangelical (free church) congregations (Vermeer \& Scheepers 2017, 21-22).

Against this background the present article aims at defining more precisely the current state of mission among free churches in Germany and at reflecting about its future viability. This is done by an analysis of 15 years of membership records (2003-2017) provided by the Bund Freier evangelischer Gemeinden (Association of Free Evangelical Churches; BFeG) in Germany, and by a case study of two congregations from this same denomination (conducted between March and October, 2016). Specifics about the BFeG will be presented in the next section. After our presentation of the data, these will be discussed and compared with other studies.

\section{Methodology}

\subsection{General}

The BFeG originated in the nineteenth century as the result of a separation from the Protestant state church. The founders of the early FeG churches insisted on a personal confession of faith in Christ as a prerequisite of church membership with a view to generating churches of conviction or believers' churches (Demandt 2012; Weyel 2013). Subsequently, as free churches in general established themselves as decidedly antitypical to a nominal people's church (Volkskirche), they, quite naturally, provoked a reaction from the ecclesial establishment that ranged from a frosty distance to outright hostility. In turn, free churches defined themselves quite ambivalently in opposition to a majority church that they encountered as their bogeyman. This ecclesial counterpart functioned as a necessary point of reference for their own identity formation and, at the same time, (through the process of differentiation) gave meaning to the free church perspective of Christian existence and piety (Bartholomä 2014). As an alternative model of church, free church minorities have, up to this day 'oriented themselves, consciously or unconsciously, intentionally or unintentionally, in thesis and antithesis, towards the mainline churches' (Geldbach 2012, 160, translation ours).

According to its website the $\mathrm{BFeG}$ is a mission-minded denomination, eager to plant new churches, and always looking for new ways to 'present the gospel 
in a contemporary and intelligible form: ${ }^{3}$ On a specialized website focused on church planting (Gemeindegründung) the BFeG's missionary strategy is further explained. ${ }^{4}$

Currently, the BFeG is one of the largest German free churches. In 2017 the denomination counted 485 congregations and 41,744 members. Children (ca. 10,000) and registered guests (ca. 15,000) are not included in this number. The denomination is divided in 23 regional circuits (Kreise), consisting of a variable number of local churches. Annually the $\mathrm{BFeG}$ grows with an average percentage of $1.2 \%$, which amounts to an absolute growth of 6,485 members since 2003 .

\subsection{Quantitative Data}

Unlike most other free church denominations the BFeG keeps meticulous membership records. With courtesy of Mr Klaus Kanwischer, Geschäftsführer (executive director) of the $\mathrm{BFeG}$, we have received all the membership records from 2003 until 2017 in Excel format. We currently know of no other set of church growth related empirical data that provide us with a similar degree of scope and precision. As described in more detail below, the numerical records at our disposal are unparalleled in that they not only account for general membership figures of the BFeG, but helpfully differentiate (for almost every local church in this denomination) between transfer and conversion growth, leavers and returnees. This set of data is also longitudinal, which includes the possibility of tracing the growth and conversion figures of each congregation over fifteen years. This will allow us to improve earlier analysis by one of us based on much more limited membership records (2011-2015) from the BFeG (Paas 2017).

Records were released on the condition that identities of separate congregations would not be revealed in connection with concrete figures. Therefore, all congregations have been anonymized. In the Excel files numerical data are presented in fourteen different categories. All categories beginning with ' 2 ' represent growth (Zugänge), and all categories beginning with ' 3 ' represent decline (Abgänge).

As for growth, not all categories are relevant or clear (see table 1). Category 2.1. represents children of church members who grew up in the congregation and have received (adult) baptism; category 2.3. is not altogether clear, while categories 2.4.-2.6. represent so-called 'transfer growth'. Thus, for our analysis we have

3 See https://www.feg.de (last accessed 11 March 2019).

4 See https://gemeindegruendung.feg.de (last accessed 11 March 2019). 
TABLE 1 Legend to the categories used in the membership records (adapted and translated)

Growth

2.1. converts from church families

2.2. converts through work of the congregation

2.3. people that have joined the church as believers

2.4. transfers from mother church

2.5. transfers from another FeG

2.6. transfers from another church

2.7. returnees

\section{Decline}

death

3.1.

transfers to a daughter church

3.2 .

transfers to another FeG

$3 \cdot 3 \cdot$

transfers to another church

$3 \cdot 4$.

deletions / corrections of

$3 \cdot 5$.

membership records

expulsions

3.6.

withdrawals

used the following categories: (a) 2.2. 'converts' who have been recruited through the (missionary) work of the congregation; and (b) 2.7. 'returnees': those who had left the church in a previous stage of their lives and have now returned. Both categories together will be defined as 'conversion growth' in this article.

As for decline, more or less the same holds true. Decline by death (3.1.) or transfer (3.2.-3.4.) are not relevant to our study, while 3.5. is not altogether clear. Thus, we have used the following categories to register decline: (a) 3.6. those who have been expelled (by applying church discipline); and (b) 3.7. those who have left the church for no other church. Both categories together will be defined as 'decline' in this article.

In the remainder of this article the following terms will be used to refer to growth and decline:

- $\mathrm{G}=$ net overall membership growth (all growth minus all decline)

- $\mathrm{CG}=$ conversion growth (categories 2.2. + 2.7.)

- $\mathrm{D}=$ decline (categories 3.6. + 3.7.)

- NCG = net conversion growth (CG minus D)

In our analysis we have looked at two possible variables affecting growth and decline: age and location. Both variables are often mentioned as important explanations of church growth (cf. Paas 2016, 125, 178-179). As for age, we have sampled all BFeG-congregations based on year of establishment, each sample covering ten years. With regard to location, we have first looked at the growth and decline of the 23 regional circuits (Kreise), and then more specifically at 
BFeG-congregations in the four largest German cities: Berlin, Munich, Hamburg and Cologne. Statistical significance was measured with Mean +/- 2xSD.

\subsection{Qualitative Data}

In addition to our quantitative analysis of BFeG membership records two extensive case studies were conducted (March-October 2016) in order to explore the contextual narratives behind the figures (cf. Bartholomä 2019). Two congregations were selected that showed good growth results-one very old (established 1862) and relatively large West German church (anonymized as Free Church for Others $=$ FCO) and one relatively young (established 2014) church plant in East Germany (anonymized as Free Church for the City = FCC). Both churches have grown rapidly. Between 2003 and 2017 FCO grew from 419 to 596 members $(+42 \%)$, while FCC since its establishment in 2014 grew from 17 to 80 members $(+370 \%)$. With well above-average CG of $5.3 \%$ (FCO) and $21 \%$ (FCC), as well as positive NCG, both congregations are exceptional and may therefore be classified as 'extreme/deviant cases'. Yet as 'good practice' examples of mission and church growth in a secular environment they are also 'critical cases' as their significance certainly extends beyond their own local context. ${ }^{5}$ For if it turns out that even our large and missionally successful congregation appeals primarily to people who already muster some faith and who are more or less churched and religiously socialized, we would probably have to assume that this is all the more true for the majority of free church communities. Besides, if a free church plant in one of the most secularized cities of East Germany is able to reach quite a few people who do not have a Christian background, it must be assumed that they have reflected intensely about their post-Christian context. We would then be dealing with a kind of 'learning laboratory' whose insights are of strategic importance when thinking about the state and future of mission among free churches.

Our overall research was guided by the following explanatory and openexplorative questions:

- Why do these particular free church congregations grow better than most others?

- To what extent does the conscious reflection of their own post-Christian or post-Christendom context play a role for these churches and their leaders?

- Which entryways have been found by these churches to an increasingly secularized population?

5 For more on the classification and selection of meaningful cases see Flyvbjerg (2011, 306-306), Yin (2014, 27-69) and Bryman (2016, 62-63). 
- Is there evidence, even in these churches with above average conversion growth, for the hypothesis mentioned above that free churches address and reach mainly people with considerable Christian socialization?

In order to answer the above questions, we have drawn on several sources of data combining them through methodological triangulation. Using the method of participant observation, we analyzed several church services as well as one evangelistic discovery group as meaningful mirrors of the churches' missional identity. In addition, we conducted two semi-structured expert interviews with pastors as well as three narrative interviews with new believers. Names of new believers were provided by the pastors, based on a request for new believers with little or no Christian background. By way of content analysis, the answers have been coded and related to the themes implied in our research questions. With a main focus on this collection of qualitative data, we have supplemented our method by a quantitative online-survey for church members. In FCO this received a $17 \%$ response (10o respondents), and in FCC $60 \%$ (40 respondents). In this survey we asked questions about the depth of their religious upbringing, their relationship with the church before joining this particular free church and the members' assessment of several characteristics pertaining to the missional effectiveness of their congregation.

\section{Presentation of Data}

\subsection{Quantitative Results}

Between $2003-2017$ the $B F e G$ has grown with 6,485 members, or $18.6 \%$. This amounts to an average annual growth of $1.22 \%$. In order to study the relationship between church age and growth, all local churches have been sampled in 10-year groups based on their planting year (see table 2).

Overall, all samples after 1948 are growing, while all samples before 1948 are in decline. In absolute numbers, the samples between 1948-2017 have grown with 7,625 members, while the older samples have lost 1,140 members. This explains the BFeG overall growth of 6,485 members. This leads to the straightforward conclusion that the younger churches as a group grow better than the older churches as a group.

With respect to conversion growth (CG), between 2003 and 2017 the BFeG gained 6,516 converts and returnees. On the average, the annual portion of CG was $2.1 \%$ of the membership. Altogether there has been a gradual relative decline in CG, from $2.5 \%$ of the membership in 2003 to $1.9 \%$ of the membership in 2017 .

Church age seems to have a positive effect on CG, as appears from the following table (see table 3 ). 
TABLE 2 BFeG membership growth in age-based samples

\begin{tabular}{|c|c|c|c|c|}
\hline \multirow[b]{2}{*}{$\begin{array}{l}\text { Year of } \\
\text { establishment }\end{array}$} & \multicolumn{3}{|c|}{ Age samples $\left({ }^{*}=\right.$ significant $)$} & \multirow[b]{2}{*}{$\begin{array}{l}\text { Annual growth } \\
2003-2017 \text { in \% }\end{array}$} \\
\hline & $N$ in 2017 & $\begin{array}{l}\text { Average members / } \\
\text { church in } 2017\end{array}$ & $\begin{array}{l}\text { Growth } \\
2003-2017 \text { in } \%\end{array}$ & \\
\hline$<1877$ & 21 & $147^{*}$ & -5 & -0.3 \\
\hline $1878-1887$ & 14 & 114 & -10.8 & -0.8 \\
\hline $1888-1897$ & 44 & 97 & -4.6 & -0.3 \\
\hline 1898-1907 & 32 & 106 & -1.7 & -0.1 \\
\hline $1908-1917$ & 32 & 104 & -6.5 & -0.4 \\
\hline $1918-1927$ & 24 & 94 & $-5 \cdot 7$ & -0.4 \\
\hline $1928-1947^{\mathrm{a}}$ & 26 & 102 & $-5 \cdot 4$ & -0.4 \\
\hline 1948-1957 & 27 & 69 & 0.4 & 0.03 \\
\hline $195^{8-1967}$ & 10 & 74 & $17 \cdot 5$ & 1.1 \\
\hline 1968-1977 & 24 & 74 & $3 \cdot 7$ & 0.2 \\
\hline $1978-1987$ & 35 & 100 & 20.6 & 1.3 \\
\hline 1988-1997 & 67 & 96 & 53.4 & 2.9 \\
\hline 1998-2007 & 69 & 57 & 194.4 & $7 \cdot 5$ \\
\hline 2008-2017 & $6 o$ & 39 & $435.2^{*}$ & 18.3 \\
\hline $\mathrm{BFeG}$ & 485 & 86 & 18.6 & 1.2 \\
\hline
\end{tabular}

a Time-span adapted due to limited number of churches (no churches were planted during the Second World War).

Compared with the BFeG average (CG: $2.1 \%$ ) the three most recent samples show a significant increase of converts:

- Sample 2008-2017:3.1\%

- Sample 1998-2007:4.7\%

- Sample 1988-1997: 3.2\%

The two samples 1958-1977 also show a significantly larger CG. However, sample $1968-1977$ (2.55\%) only barely exceeds the range of normality $(2.53 \%)$, while sample $1958-1967$ is the smallest sample with only 11 churches (one of which is performing far above average; without this church the sample would fall back into the range of normality). Therefore, it is better not to include these two samples as examples of significant CG.

The two samples 1878-1897 and the four samples between 1908 and 1957 show a significantly lower $C G$ than the $B F e G$ average, while the oldest sample 
TABLE 3 CG in age-based samples

\begin{tabular}{|c|c|c|}
\hline \multirow[b]{2}{*}{$\begin{array}{l}\text { Year of } \\
\text { establishment }\end{array}$} & \multicolumn{2}{|c|}{ Age samples $\left({ }^{*}=\right.$ significant $)$} \\
\hline & $\begin{array}{l}\text { Total number of converts } \\
2003-2017\end{array}$ & $\begin{array}{l}\text { Average CG as annual } \\
\text { portion of membership in } \\
\%, 2003-2017\end{array}$ \\
\hline$<1877$ & 533 & 2.1 \\
\hline $1878-1887$ & 97 & $0.7^{*}$ \\
\hline $1888-1897$ & 437 & $1.2^{*}$ \\
\hline $1898-1907$ & 578 & 2.1 \\
\hline $1908-1917$ & 305 & $1.1^{*}$ \\
\hline $1918-1927$ & 289 & 1.6 \\
\hline $1928-1947$ & 289 & $1.3^{*}$ \\
\hline 1948-1957 & 232 & 1.6 \\
\hline $195^{8-1967}$ & 237 & 2.6 \\
\hline $1968-1977$ & 362 & 2.6 \\
\hline $1978-1987$ & 541 & 2.1 \\
\hline 1988-1997 & 1364 & $3.2^{*}$ \\
\hline $1998-2007$ & 1010 & $4 \cdot 7^{*}$ \\
\hline 2008-2017 & 242 & $3.1^{*}$ \\
\hline $\mathrm{BFeG}$ & 6516 & 2.1 \\
\hline
\end{tabular}

$(<1877)$ and the sample 1898-1907 perform average $(2.1 \%)$. However, the oldest sample's results are influenced by the results of one single church, which performs far above average. This church is discussed in section 3.2 of this article, and referred to as ' $\mathrm{FCO}$ '.

As regards decline (D), between 2003-2017 the BFeG lost 9,980 members due to expulsion (church discipline) and church leaving. On the average $3.1 \%$ of the membership left the church annually. Altogether there has been a slight increase in the number of church-leavers, with percentages under $3 \%$ before 2008 and above $3 \%$ since 2009 .

Thus overall BFeG's NCG (CG minus D), is negative: between 2003 and 2017 3,464 more members left the church than entered it by conversion $(9,980-$ $6,516)$. This amounts to $0.9 \%$ of the membership annually.

When we look at the age variable, it is clear that by and large younger churches lose more members to expulsion/leaving than older churches (see table 4). 
TABLE $4 \quad \mathrm{D}$ in age-based samples

\begin{tabular}{|c|c|c|}
\hline \multirow[b]{2}{*}{$\begin{array}{l}\text { Year of } \\
\text { establishment }\end{array}$} & \multicolumn{2}{|c|}{ Age samples $\left({ }^{*}=\right.$ significant $)$} \\
\hline & $\begin{array}{l}\text { Total number of } \\
\text { leavers } 2003-2017\end{array}$ & $\begin{array}{l}\text { Average D as annual } \\
\text { portion of membership } \\
\text { in } \% 2003-2017\end{array}$ \\
\hline$<1877$ & 628 & 2.5 \\
\hline $1878-1887$ & 231 & $1.7^{*}$ \\
\hline $1888-1897$ & 779 & $2.2^{*}$ \\
\hline $1898-1907$ & 685 & 2.5 \\
\hline $1908-1917$ & 614 & $2.2^{*}$ \\
\hline $1918-1927$ & 627 & $3 \cdot 5$ \\
\hline $1928-1947$ & 675 & 3.1 \\
\hline $1948-1957$ & 459 & 3.1 \\
\hline $195^{8-1967}$ & 226 & 2.5 \\
\hline 1968-1977 & 527 & $3 \cdot 7$ \\
\hline $1978-1987$ & 1062 & $4^{*}$ \\
\hline 1988-1997 & 1916 & $4 \cdot 3^{*}$ \\
\hline 1998-2007 & 1313 & $5 \cdot 3^{*}$ \\
\hline $2008-2017$ & 238 & 3.8 \\
\hline BFeG & 998 o & 3.2 \\
\hline
\end{tabular}

Three samples lose significantly more members to $\mathrm{D}$ than the $\mathrm{BFeG}$ average $(3.2 \%)$ :

- 1978-1987:4\%

- 1988-1997:4.3\%

- 1998-2007:5.3\%

Other samples do not lose significantly more members to D than the BFeG average, but it is striking to see that the five youngest samples (1968-2017) lose the most. As the youngest sample (2008-2017) covers only 10 years (vs. 15 years in all the other samples), it might go to the top of the list in the next years. This would show a neat chronological order of decline.

On the other hand, the five oldest samples $(<1877-1917)$ all show a (mostly significantly) lower D than the younger churches. In order of size, and related to the $\mathrm{BFeG}$ average:

- 1878-1887: 1.7\%*

- 1888-1897: $2.2 \%$ *

- 1908-1917:2.2\%* 
TABLE 5 NCG in age-based samples

Age samples (no significant results)

\begin{tabular}{lll}
$\begin{array}{l}\text { Year of } \\
\text { establishment }\end{array}$ & $\begin{array}{l}\text { TotalNCG } \\
2003^{-2017}\end{array}$ & $\begin{array}{l}\text { Average NCG as } \\
\text { annual portion of } \\
\text { membership in \% } \\
2003^{-2017}\end{array}$ \\
& & -0.4 \\
$<1877$ & -95 & -1 \\
$1878-1887$ & -134 & -1 \\
$1888-1897$ & -342 & -0.6 \\
$1898-1907$ & -107 & -1.1 \\
$1908-1917$ & -309 & -1.9 \\
$1918-1927$ & -338 & -1.8 \\
$1928-1947$ & -386 & -1.5 \\
$1948-1957$ & -227 & 0.1 \\
$1958-1967$ & 11 & -1.2 \\
$1968-1977$ & -165 & -1.9 \\
$1978-1987$ & -521 & -1.2 \\
$1988-1997$ & -552 & -1.6 \\
$1998-2007$ & -303 & -0.7 \\
$2008-2017$ & 4 & -1.1 \\
BFeG & -3464 & \\
\hline
\end{tabular}

- <1877:2.5\%

- 1898-1907: 2.5\%

All this leads to a clear conclusion: younger churches lose more members due to $\mathrm{D}$ than older churches. This may level out their differences in performance when it comes to NCG (CG minus D), and this is indeed what appears from our analysis.

No significantly higher or lower NCG was found in any sample (see table 5 ). However, all samples but one (the very small 1958-1967 sample with $0.1 \%$ ) have a negative NCG. This is also true for the youngest sample, even while it has a slightly positive NCG in absolute numbers $(+4)$. This is due to the fact that it alternates years with very negative NCG with years that have better NCG, so that the absolute result is positive while the average percentage in terms of NCG in relation to membership is negative.

With regard to NCG there is no clear pattern related to church age. All samples score between o.1\% (1958-1967 sample) and -1.9\% (1918-1927 and 1987-1987 
samples). The two best performing samples (<1877 with $-0.4 \%$, and $1958-1967$ with $0.1 \%$ ) are influenced very strongly by the exceptional results of one single congregation. It is therefore better to take these figures with caution.

Conclusion: there is no clear pattern of NCG related to church age. In other words, the significantly higher CG of the younger samples is compensated by their significantly higher D. Older churches attract (far) less converts, but also lose fewer members to expulsion and church leaving.

To what extent is location a relevant variable? As far as BFeG circuits (Kreise) go, it is clear that membership growth $(G)$ is unevenly distributed. Six out of the 23 circuits are shrinking, and 11 out of 23 circuits are performing below the $\mathrm{BFeG}$ total of $18.6 \%$ growth over 2003-2017. CG follows more or less the same pattern with the same circuits performing above or under the BFeG average. ${ }^{6}$ This suggests that $\mathrm{G}$ correlates with $\mathrm{CG}$, that is: churches showing a good overall membership growth generally also show a better conversion growth. The same goes for underperformance. Decline and NCG, however, do not seem to follow a geographical pattern. The only exception is the Berlin-Brandenburg circuit that seems to reflect the more favourable CG and NCG of the city of Berlin (see below, table 6).

As for the cities in particular, it is a well-established fact that currently major cities on the whole show better church growth than other places, due to demographics, immigration, economic activity (job market), and initiatives of church renewal. Does this apply for BFeG results in Germany? Below results are listed for all >1million cities in Germany: Berlin, Munich, Hamburg and Cologne.

TABLE 6 G, CG, D, and NCG in the four large cities

\begin{tabular}{lllll}
\hline & Berlin & Munich & Hamburg & Cologne \\
\hline Number of churches in 2017 & 11 & 6 & 13 & 6 \\
Membership in 2017 & 744 & 719 & 1330 & 465 \\
G in 2003-2017 & 444 & 292 & -80 & 103 \\
G in \% & $148 \%$ & $68.4 \%$ & $-5 \cdot 7 \%$ & $30.8 \%$ \\
CG in 2003-2017 & 169 & 168 & 241 & 129 \\
D in 2003-2017 & 68 & 157 & 251 & 175 \\
NCG in 2003-2017 & 101 & 11 & -10 & -46 \\
\hline
\end{tabular}

6 The only exception is Norddeutscher Kreis, that performs slightly above BFeG average in terms of CG, while it was underperforming in terms of membership growth. 
Clearly, Berlin and Munich are affirming the urban trend, while Hamburg and Cologne show decline (Cologne reached its peak of 549 members in 2011, and is in decline since then). In Berlin only two out of the eleven churches that existed in 2017 have a negative NCG. Results are skewed somewhat, though, by an outlier score of one church in 2011. Nevertheless, seven out of the eleven churches that still existed in 2017 have a positive NCG, and results would have been positive too if the outlier church is excepted. Moreover, since 2003 each single year except 2009 had a positive NCG score overall.

In Munich two out of the six churches that existed in 2017 have a positive NCG. Results are largely dependent on the high scores of one church. If this church were excepted, results would have been negative. Also, only four out of the eight measuring points were positive, especially the last two (2015 and 2017). Therefore the results in Munich are more unevenly distributed and largely dependent on one church. Altogether it would be safe to assume that Berlin is the only German city where the BFeG shows a clear positive NCG.

All this leads to the following conclusions based on a quantitative analysis of the BFeG membership records (2003-2017):

1. Younger churches show (far) better overall $G$ than older churches.

2. Younger churches show better CG than older churches.

3. Both with regard to geography and church age there is a positive correlation between $\mathrm{G}$ and $\mathrm{CG}$ : churches that grow better overall also draw more converts.

4. Younger churches lose more members to expulsion and church leaving than older churches.

5. In terms of NCG (CG minus D) there is no significant difference between older and younger churches.

6. The cities of Munich and especially Berlin show positive NCG. Especially the Berlin churches show better NCG than any other sample in the BFeG.

\subsection{Qualitative Results}

Due to space restraints we will only present here a cross-case summary correlating the results of our two 'good practice' case studies. We will especially focus on the missional praxis, the contextual awareness and the previous 'religious texture' of those attracted by these two urban churches.

\subsubsection{Missional Praxis}

It is evident that the above-average CG in both churches correlates with a special emphasis on the call to mission. Both among leaders and many church members there is an observable missional passion, which is why they work with high intensity and focus to bring people to faith. In addition, in the FCO as 
well as the FCC, members of the church community are strongly encouraged to adopt an evangelistic lifestyle and to consciously nurture natural relationships with non-Christians. This is due to the experience that, under normal circumstances, non-Christians only start to engage with the Christian story if they are in an authentic relationship with a member of the church. The manifold training and recruitment programs offered by churches usually do not generate a large missional impact if they are not embedded in a framework of cultivated relationships. In our two case studies almost all new converts that have been interviewed were drawn towards church and faith by what they repeatedly called 'word-of-mouth recommendation' from a friend or close acquaintance already related to their particular free church congregation. At the same time, all interviewed pastors are unanimously of the opinion that the lack of intensive personal contacts with non-Christians currently stands out as one of the main obstacles for mission and conversion growth.

In addition, it becomes clear that both churches are dependent on their members' readiness to actually bring friends and acquaintances into contact with their faith community. The strong emphasis on relationship-building with 'unchurched' people notwithstanding, the missional strategy of both congregations is still essentially structured around central church programs such as worship services or discovery groups. In this context, especially the pastors are fully aware of the fact that the fundamental readiness of their members to invite or bring seekers to church is significantly influenced by the perceived quality of these programs.

At this point, there are observable differences between our two 'case congregations'. It is noticeable that the requirements of a missionally appealing worship service, clearly expressed by both churches, are not put into practice with equal consistency. While at the FCO a seeker-sensitive approach to worship is certainly envisaged in theory, in reality, however, one cannot generally assume that each service is compatible with the cultural and religious preconditions and aesthetic sentiments of secular non-Christians. This results, in turn, in a latent uncertainty which is taken note of among the church leadership as having a dampening effect on the motivation and candor among its membership to regularly invite non-members. In the FCC the basic confidence in the context-sensitive design of various church programs as well as the perceived relevance of their content for secular visitors is more pronounced and evidently constitutes an essential factor for its missional 'effectiveness'. This is also reflected in the fact that especially new converts and even those who are not yet believers repeatedly feel the desire to invite friends to this particular free church. 
Finally, it is one of the essential characteristics of both 'good practice congregations' to create an atmosphere that allows outsiders to cautiously approach the church and its faith tenets in self-imposed proximity or distance. Thus, in both cases, the presence of a hospitable climate of acceptance and appreciation appears to be crucial for their missional 'success'. This is underscored by the fact that on the basis of their own experience, almost all new converts unequivocally sense the importance of explicitly welcoming nonbelievers, encouraging them to express their doubts and critical reservations and giving them time and space to honestly explore the content and praxis of the Christian faith.

\subsubsection{Contextual Awareness}

In the $\mathrm{FCO}$ the challenge of necessary contextualization into a postmodern environment is consciously perceived from a specifically missional perspective. It is clearly recognized that the Christian message has to be unfolded against the backdrop of an increasingly post-Christian society and must be connected with the cultural sensibilities, feelings and questions of life of secular contemporaries in a relevant way. The most fundamental criteria for the current implausibility of faith, the essential barriers to fruitful faith communication (such as the tension between Christian sexual ethics and culturally established moral values), as well as the general conditions of faith in a secular age, are extensively reflected upon by the leaders of this church. However, according to their own self-critical assessment, no sustainable and promising access routes to the growing secular segments of the population have yet been found. In this regard, the observable church praxis (e.g., the design of worship services, the character of preaching or the implied reader of the church's website) gives the impression that one still assumes a rather high Christian socialization among its contacts. In fact, a significant amount of Christian socialization may still be partially existent in the strongly Catholic environment of the FCo. Yet, those who are more distant from church and faith remain largely unaddressed. The same is true with regard to adherents of 'new spirituality', who are certainly taken into consideration in private conversations and interviews, but are not specifically referred to in the evangelistic and apologetic public discourse of the church.

In view of its more secular and unchurched environment in East Germany, the FCC is (even more so than the FCO) confronted with the urgent task of considering its contextual location and to adjust its missional activity accordingly. As a younger church plant, the FCC demonstrates a more recognizable adaptation to its secular surroundings than the FCO. It deliberately follows 
a process of active contextualization, the aim of which is to better understand the specifically East German culture in order to more effectively communicate the content of the Christian faith. The establishment of a coffee shop may serve as an example here. Early in the church planting process it was created as a public 'third place' and has to be understood as an incarnational entryway into the 'living environment' of the urban target group. The leaders of the FCC have internalized the fact that the cultural climate has changed rapidly in recent decades and it is again very evident from our collected data that post-Christian views and life-styles have not just been reflected upon theoretically, but are actually taken into account when it comes to specific church praxis. This is demonstrated by the ability to communicate theological doctrine which secular people would normally find hard to swallow, in an emotionally appealing and cognitively understandable way. Especially in worship services the pastors take great pains to sensitively counter possible difficulties of comprehension or feasible objections. This is even true when it comes to the missional challenge presented by those who are somewhat 'religiously indifferent' (yet may be invited to church for some reason). Considering the answers of our newly converted interviewees, it appears to be missionally promising and potentially fruitful to awaken a deepened spiritual interest among seekers as well as religiously rather apathetic contemporaries by means of targeting deep-rooted human longings. This may create some apologetic force, especially where people begin to understand the gospel of Jesus Christ as a response to their own variety of unfulfilled desires.

\subsubsection{Previous 'Religious Texture'}

First of all, there are several indications that in the FCO only a very small proportion of those who newly join the congregation can be truly regarded as formerly unaffiliated. Although the majority of new converts may well be classified as previously 'unfreechurched' (freikirchenfern), they are still endowed by and large with an 'ecclesial imprint' and Christian socialization. The overall picture suggests that the older of our two case study churches primarily reaches out to people with whom it is possible to tie in with already existing Christian foreknowledge or some kind of prior relationship with the church. As far as the FCC is concerned, it should be noted that many of its newcomers also have some previous knowledge of the Christian faith or have been attached to the church before in some way or another. Nevertheless, in this young congregation, there are more people who turn to the Christian faith from nonchurched backgrounds, and with a very low degree of Christian socialization.

In this context we ought to take note that in our two 'good practice' churches the traditional 'revivalistic mode of operation' which has long been 
characteristic for classical free churches (cf. 1. above) is evident in varying degrees. By all accounts, most of the conversions in the older FCO may be described as a 'reassurance' (Vergewisserung) or a 'rediscovery' (Entdeckung) of faith, ${ }^{7}$ i.e., an awakening of already existing latent faith. This is consistent with the observation that this free church is especially attractive to those who come out of Christian backgrounds, have lost sight of God and the church due to negative church experiences and now encounter a more vibrant faith again. With regard to secular people without such particular Christian socialization, the FCO obviously finds it rather difficult to develop missional 'effectiveness'. Together with the above-mentioned habit of assuming (at least unconsciously) a certain amount of religious knowledge or church experience this shows that the FCO continues to be attached to the free church legacy of revivalism.

By contrast, the FCC has more notably left behind the traditional 'mode of revival' and thus, from a missional perspective, explicitly perceives secular contemporaries with little Christian foreknowledge as their most meaningful 'significant others'. With regard to the conversion processes within the FCC, both types of 'reassurance' and 'rediscovery' are comparably less important than in the FCO. Having said that, conversions that do occur frequently amount to 'watershed experiences' (Lebenswende). ${ }^{8}$ On the one hand, this is due to the fact that indeed a large segment of this church's East German environment is comprised of people very far from faith and church. On the other hand, these conversions are also the fruit of its conscious efforts to address and reach those with no substantial Christian socialization or previous affiliation with the church. Insofar, the missional praxis of the FCC has significantly less 'revivalistic traits' as is the case with the FCo.

Discussion

To some extent our data confirm the assumption that in a secularizing context free and evangelical churches fare better than so-called mainline churches. While the large Protestant and Roman-Catholic churches in Germany have suffered massive losses, the BFeG has experienced consistent growth over the years (an average of $1.22 \%$ annually). Also its attraction to non-churched people seems stronger overall. Tentative calculations based on limited data

7 These different 'conversion types' have been classified by Zimmermann and Schröder (2010, 29-30).

8 Ibid. 
suggest, for example, that the Protestant Church in Germany welcomes 35,000-40,000 newcomers per year, both initiates and returnees (Paas 2016, 160). With a total membership of ca. 21 million, this would amount to ca. 1 newcomer per $55^{\circ}$ members per year (o.18\% per year). The BFeG performs far better in this respect, with an annual conversion growth of $2.1 \%$.

The hypothesis that free church mission predicates on a 'revivalistic' pattern, aiming at so-called 'nominal' Christians or somewhat alienated members of larger churches is also confirmed. Our case studies clearly show how this pattern stamps the attempts of the FCO (both strategically and in terms of religious background of its converts), and we would argue (as we hinted at above) that if even such a missionally minded congregation appeals primarily to people with substantial Christian socialization this is probably true a fortiori for the vast majority of free churches. This particular kind of revivalism is also suggested by our quantitative data. Conversion growth in the BFeG is subsiding over the years, from $2.5 \%$ in 2003 to $1.9 \%$ in 2017 , suggesting a drying 'pond' of potential converts in the membership of the larger churches. This lines up well with the observation by Vermeer and Scheepers (2017), that the growth of evangelical churches in the Netherlands largely depends on the availability of orthodox believers in other churches and on the receptivity of the mainstream culture towards evangelical beliefs and values. This does not necessarily affect the growth of individual free churches in every single location, but it will certainly affect the overall growth of free churches if this growth stays dependent on the revivalistic strategy of offering faith renewal to nominal or lapsed Christians. The fact that decline in the $\mathrm{BFeG}$ is slightly increasing over the years may point to a decreasing receptivity in the mainstream culture towards its evangelical values.

Our data also suggest, however, that free churches in (very) secularized areas and urban centres may perform better in terms of evangelism and recruitment than elsewhere. This may sound paradoxical, but it can be explained partly by the simple fact that potential recruits in such contexts are more often secularized, and also by the observation that churches in these areas are more often the result of intentional church planting. This would provide them with a more entrepreneurial attitude, and possibly more mission-minded leadership (as can be seen, e.g., in our urban FCC case study). Berlin, for example, has been deemed as an 'avowedly secular' city (Schiffauer 2013, 165; cf. Boy 2015, 28), but at the same time it is the scene of vigorous church planting (Boy 2015). Our city-based samples showed that the eleven BFeG-churches in Berlin experienced strong net conversion growth (conversion minus decline), and that the Berlin sample in fact was the only BFeG sample with a positive net 
conversion growth. Other research shows that actual investment in evangelism (rather than missional rhetoric or beliefs) are good predictors of recruitment success (Paas \& Vos 2016). This may be in better supply in newer churches, as they are more often led by entrepreneurial leaders (Boy 2015, 108-118; Foppen et al. 2018). However, it should be noted that not just younger BFeGchurches in Berlin are performing well, so apparently the urban context is also a factor to be reckoned with.

A curious observation, finally, is the fact that newer churches in the BFeG not only show far better growth and conversion growth, but also far more decline in terms of church leaving and expulsion. Overall, this results in net conversion rates that do not really deviate from the average rates in the BFeG. This confirms older research based on a more limited sample (2011-2015) of $\mathrm{BFeG}$ churches (Paas 2017). There it is stated that these figures hint at a 'fast metabolism' in these younger churches.

Apparently, their organizational dynamic attracts many newcomers, but then it has trouble keeping them. This combination makes sense, if we consider that people who reverse their decisions will usually do so relatively shortly after they have made one. We may expect that a high proportion of joiners (either converts or transfers) will reconsider their decision afterward, with some deciding to leave.

PAAS 2017,13

In terms of mission strategy, our study suggests that if churches want to grow through conversions they should consider planting new churches and concentrate on the cities. Also, especially new churches should invest in 'member satisfaction' as their apparent dynamic organization pushes out many members. A major challenge for the mission of the free churches (in fact, for all churches), however, is to process the drying pond of potential initiates with some Christian socialization. Our case study of the East German church (which indeed turns out as a possible 'strategic learning laboratory') and our data from the Berlin sample suggest that this would require a combined effort of intentional church planting, strong entrepreneurial leadership, consistent reflection on a secularized context, and an audacious commitment to applying the necessary measures in the organization and theology of the church. There are no simple solutions here, but this does not mean that there is nothing the church can do. After all, secularization is related to 'particular historical and social conditions, which can be countered or utilized by human ingenuity and imagination' (Martin 2002, 156; cf. Boy 2015, 119-128). 


\section{Conclusions}

In our 'secular age', where the former realities of a Christendom culture are quickly fading, the conventional procedures and evangelical strategies of mission and recruitment seem increasingly less effective. In fact, it becomes clear how the free churches have been in symbiosis with the Christendom experience, drawing their membership mostly from the margins of the larger 'established' churches and from a Christianized mainstream culture at large, and that they suffer just as well from the disappearance of this culture. Today, it can no longer be assumed that people know what Christianity is, let alone that they have a comprehension of or appreciation for the most basic Christian narratives, theological concepts or ethical convictions (see, e.g., McLeod \& Ustorf 2003; Murray 2018). Thus, it seems obvious that a movement whose missional mode has naturally been dependent on the existence of a certain Christian groundwater level now faces severe challenges under the changed conditions of a largely post-Christian environment. Further research may reveal, for example, how entrepreneurial leadership affects the (conversion) growth of churches and which locations are most conducive for growth.

\section{References}

Bartholomä, P. (2014). The Self and the Collapsed Other: Towards Defining Free Church Identity and Mission in a Post-Christendom Age. Baptistic Theologies 6/2, 53-73.

Bartholomä, P. (2015). The Ecclesiological Self and the Other: Concepts of Social Identity and Their Implications for Free Churches in Secular Europe. Ecclesial Practices 2, 146-166.

Bartholomä, P. (2017). Gibt es eine freikirchliche 'Krise der Mission'? Eine kritische Bestandsaufnahme. Freikirchenforschung 25, 218-236.

Bartholomä, P. (2019). Freikirche mit Mission: Perspektiven für den freikirchlichen Gemeindeaufbau im nachchristlichen Kontext. Leipzig: Evangelische Verlagsanstalt. Boy, J. (2015). Blessed Disruption: Culture and Urban Space in a European Church Planting Network. New York: CUNY Academic Works.

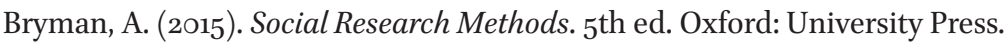

Demandt, J. (ed.) (2012). Freie evangelische Gemeinden. Göttingen: Vandenhoeck \& Ruprecht.

Flyvbjerg, B. (2011). Case Study. In: N. Denzin, Y. Lincoln (eds.). The Sage Handbook of Qualitative Research. 4th ed. Thousand Oaks: Sage, 301-314. 
Foppen, A. et al. (2018). Personality Traits of Church Planters and Other Church Leaders in Europe (II). Journal of Empirical Theology 31, 288-308.

Geldbach, E. (2005). Freikirchen-Erbe, Gestalt und Wirkung. 2nd ed. Göttingen: Vandenhoeck \& Ruprecht.

Großbölting, Thomas (2013). Der verlorene Himmel: Glaube in Deutschland seit 1945, Göttingen: Vandenhoeck \& Ruprecht.

Martin, D. (2002). Believing without Belonging: A Commentary on Religion in England. In: D. Martin, Christian Language and Its Mutations: Essays in Sociological Understanding. Aldershot: Ashgate.

McLeod, H. \& Ustorf, W. (eds.) (2003). The Decline of Christendom in Western Europe. 1750-2000. Cambridge: University Press.

Meulemann, H. (2015). Nach der Säkularisierung: Religiosität in Deutschland 1980-2012. Wiesbaden: Springer.

Murray, S. (2018). Post-Christendom: Church and Mission in a Strange New World. 2nd ed. Eugene: Cascade.

Paas, S. (2016). Church Planting in the Secular West: Learning from the European Experience. Grand Rapids: Eerdmans.

Paas, S. (2017). A Case Study of Church Growth by Church Planting in Germany: Are They Connected?. International Bulletin of Mission Research 42, 1-15.

Paas, S. \& A. Vos (2016). Church Planting and Church Growth in Western Europe: An Analysis. International Bulletin of Mission Research 40, 243-252.

Schiffauer, W. (2013). Secular Resistance and First Post-Secular Steps: How Berlin Deals with Global Prayers. In: J. Becker et al. (eds.). Global Prayers: Contemporary Manifestations of the Religious in the City. Viadrina: Lars Müller Publishers, 165-177.

Schröder, S. (2007). Konfessionslose erreichen: Gemeindegründungen von freikirchlichen Initiativen seit der Wende 1989 in Ostdeutschland, Neukirchen: Neukirchener.

Stolz, J. \& Favre, O. et al. (2014). Phänomen Freikirchen: Analysen eines wettbewerbsstarken Milieus. Zürich: Pano.

Vermeer, P. \& Scheepers, P. (2017). Umbrellas of Conservative Belief: Explaining the Success of Evangelical Congregations in the Netherlands. Journal of Empirical Theology 30, 1-24.

Voigt, K. H. (2004). Freikirchen in Deutschland (19. und 20. Jahrhundert), Leipzig: Evangelische Verlagsanstalt.

Weyel, H. (2013). Evangelisch und frei-Geschichte des Bundes Freier evangelischer Gemeinden in Deutschland. Witten: Bundesverlag.

Yin, R. (2014). Case Study Research: Design and Methods. 5th ed. Thousand Oaks: Sage.

Zimmermann, J. / Schröder A.-K. (eds.) (2010). Wie finden Erwachsene zum Glauben? Einführung und Ergebnisse der Greifswalder Studie. Neukirchen: Neukirchener. 